\title{
VARIATIONAL METHODS OF FORMING DEPRECIATION DEDUCTIONS
}

\author{
Evgeniy Aleksandrovich Filatov, \\ Liliya Gennadyevna Rudykh and Yuvenaliy Anatolievich Kiryukhin
}

The National Research Irkutsk State Technical University,

Russian Federation, 664074, Irkutsk, Lermontov Street 83, Russia

Received 2013-12-28; Revised 2014-01-22; Accepted 2014-02-08

\begin{abstract}
Long-term planning of activity at all and the financial one in particular is one of the cornerstones of modern management. Using of author's method to form depreciative policy allows to cut uncertainty while making decisions connecting with commercial organizations' development. The article is devoted to finding optimal strategies for depreciation calculation by comparative analysis of the straight-line and proposed by the authors methods. It presents a new method of variational calculations of depreciation policy based on the handling of the introduced by the authors coefficients (linear, step and correction coefficients), allowing to an economic entity to reasonably form and distribute the amortization fund in accordance with the market situation.
\end{abstract}

Keywords: Depreciation Policy, Depreciation, Investments, Straight-Line Method, The Coefficients

\section{INTRODUCTION}

The amortization system is an important economic tool which guarantees the minimum amount of necessary own investment funds for enterprises to operate. It is in an intimate relation with the tax system, pricing and, consequently, with the interests of both the state and the society.

The development of an economically efficient depreciation policy is a very complex and multifaceted problem. It is necessary to take into account the peculiarities of every single stage of the economic development in order to find the most appropriate and optimal variant of its solution (Altahat et al., 2012).

The depreciation policy mainly consists in the choice of the transfer rate of the value of fixed assets or intangible assets to the cost of products or services and at the same time in the choice of the rate of accumulation of amortization funds for their replacement.

One of the most important sources of financing for investment both in size and accessibility for investors is depreciation. In practice there exist various means to write the cost of fixed and intangible assets off by way of depreciation (Auerbach, 1983). Since the accrued amount of amortization (depreciation) is one of the elements of the cost structure and it ultimately affects the outcome of the financial and economic activities, the choice of method of depreciation is one of the crucial elements of the accounting policy of an organization (Cohen, 1975).

The capital as a factor of production represents the production equipment funds. In order for the capital to make a profit in the production process it is necessary to constantly maintain it in a cost-effective initial state. Its inevitable depreciation should not affect the commercial activities of the enterprise (Cohen, 1980).

With the purpose to avoid losses and maintain the profitability of the capital assets the organization makes provision for depreciation consisting of the money funds intended to compensate the capital depreciation (Hulten and Wykoff, 1996). The provision for depreciation on the full capital recovery is made out of the income earned by the sales of goods produced using capital funds and, actually, the depreciation is included in the cost of the goods produced by these capital funds and

Corresponding Author: Evgeniy Aleksandrovich Filatov, The National Research Irkutsk State Technical University, Russian Federation, 664074, Irkutsk, Lermontov Street 83, Russia 
it represents the transfer of the cost of gradually depreciating fixed assets to the cost of the manufactured products. Therefore, the depreciation is a process of reproduction of the capital; the faster is its restoration, the more efficient is the business activity of the organization (Hall and Jorgenson, 1967). This is especially true in view of the rapid scientific and technological progress, the increase in the research intensity of production and the reduction of the life cycle of most capital assets.

Traditional depreciation methods applied in practice have several drawbacks (Doms, 1996). For instance, the direct method or straight-line method (Feldstein, 1982) is appropriate for those types of assets the depreciation rate for which is determined in terms of useful life or for which it is not possible to functionally relate the process of transfer of the value of assets to the production through depreciation with the intensity of their use.

The disadvantages of the straight-line depreciation also include:

- A priori fixed unchanging value of the depreciation period

- Insufficiently stimulating effect on improving the efficiency of the fixed capital utilization

- Possibility of under-depreciation due to an insufficient consideration of the effect of moral depreciation

- Insufficient consideration of the conditions of the fixed capital internal utilization

The method of calculation of depreciation proportionally to the volume of the work performed (production method) is based on the fact that the depreciation is only a result of the exploitation and time intervals play no role in the process of its calculation. Hence, this method should be applied in the case when the return of the asset during its useful life can be determined with a sufficient accuracy. Furthermore, this method does not give a clear idea of the trends of depreciation changes because of sudden fluctuations of the depreciation value from year to year.

When using the method of the reduced (declining) residue (declining-balance method) the initial value of the asset will never be written off. The decliningbalance method is based on the same principle as the sum-of-the-years of useful life method of depreciation digits method. These methods allow to write off the cost of the maximum amortization already in the first years of the asset operation. When using the sum-ofthe-years method one may apply the inverse cumulative number and slow the depreciation cost down in the first years of the asset operation. However, unlike the methods we propose this method gives sharper fluctuations of the depreciation value from year to year (Fullerton and Gordon, 1983).

\section{DATA AND METHODS}

The methods we introduce below (Filatov, 2013) resolve all the problems typical for traditional depreciation.

Our methods are based on the fact that the annual amount of depreciation is determined on the basis of the initial or current (reconstructive, in the case of revaluation) cost and the rate of depreciation calculated on the basis of the useful life of an asset, as well as of the ratio of the linear, step and correction coefficients.

Next, we test our methods for calculation of depreciation under the initial value of an asset $C$ equal to 58500 thousand dollars.

In the calculations $\mathrm{n}$ stands for the useful life of the fixed asset. For Ex. 1 let $\mathrm{n}$ be equal to 15 years (any odd number of years) (Fig. 1, Table 1-4). For Ex. 2 let $n$ be equal to 14 years (any even number of years) (Fig. 2, Table 5-8).

In the calculations $\mathrm{m}$ is the linear coefficient which determines the average depreciation rate calculated according to the remaining useful life of the asset. The calculation of the linear coefficient is done by the formula: $m=1 / n$. In Ex. 1 we thus obtain $m=$ $0,0666667(\mathrm{~m}=1 / \mathrm{n}=1 / 15)$ and for Ex. $2 \mathrm{~m}=0,07143$ $(\mathrm{m}=1 / \mathrm{n}=1 / 14)$.

In the calculations based on the authors' methods the step coefficient $\mathrm{f}$ is used in addition. This coefficient determines the amount of deviation between the depreciation values at different periods. The step coefficient is defined by the formula: $f=1 / n^{2}$. Hence the step coefficient in Ex. 1 equals 0,00444 ( $\mathrm{f}=1 / \mathrm{n}^{2}=$ $1 / 225)$ and in Ex. 2 it is $0,00510\left(f=1 / n^{2}=1 / 196\right)$.

A key regulator of depreciation is the correction coefficient K, which establishes the relationship between the linear and step coefficients and is defined independently. Depending on the managerial tasks this coefficient determines the initial acceleration or deceleration of depreciation.

When using our methods the following mandatory conditions should be satisfied:

- The difference between the value of the linear coefficient and the product of the step and correction coefficients should not be less than zero: $\mathrm{m}-\mathrm{K}^{*} \mathrm{f}>0$

- The sum of all correction coefficients should be equal to zero: $\sum \mathrm{K}=0$

- $\mathrm{K}<\mathrm{n}$ 
Evgeniy Aleksandrovich Filatov et al. / American Journal of Applied Sciences 11 (4): 631-638, 2014

Table 1. Calculation of depreciation by the authors' and the straight-line methods with the planned acceleration step $\mathrm{f}$

\begin{tabular}{|c|c|c|c|c|c|c|}
\hline \multirow[b]{2}{*}{ Period } & \multirow[b]{2}{*}{$K$} & \multicolumn{3}{|c|}{ Authors' method no. 1 (by an odd number of years) } & \multicolumn{2}{|c|}{ Straight-line method } \\
\hline & & $(m+K * f)$ & $* 100 \%$ & $\begin{array}{l}\text { Sum, thousand dollars } \\
\mathrm{C} *\left(3^{*} 4\right) / 100\end{array}$ & $\mathrm{~m} * 100 \%$ & $\begin{array}{l}\text { Sum, thousand dollars } \\
C^{*}(6 / 100)\end{array}$ \\
\hline 1 & +7 & $m+7 f$ & 9,77 & 5718 & 6,67 & 3900 \\
\hline 2 & +6 & $m+6 f$ & 9,33 & 5458 & 6,67 & 3900 \\
\hline 3 & +5 & $m+5 f$ & 8,89 & 5199 & 6,67 & 3900 \\
\hline 4 & +4 & $\mathrm{~m}+4 \mathrm{f}$ & 8,44 & 4939 & 6,67 & 3900 \\
\hline 5 & +3 & $m+3 f$ & 8,00 & 4679 & 6,67 & 3900 \\
\hline 6 & +2 & $m+2 f$ & 7,55 & 4419 & 6,67 & 3900 \\
\hline 7 & +1 & $\mathrm{~m}+\mathrm{f}$ & 7,11 & 4160 & 6,67 & 3900 \\
\hline 8 & 0 & $\mathrm{~m}$ & 6,67 & 3900 & 6,67 & 3900 \\
\hline 9 & -1 & $m-f$ & 6,22 & 3640 & 6,67 & 3900 \\
\hline 10 & -2 & $m-2 f$ & 5,78 & 3381 & 6,67 & 3900 \\
\hline 11 & -3 & $m-3 f$ & 5,33 & 3121 & 6,67 & 3900 \\
\hline 12 & -4 & $m-4 f$ & 4,89 & 2861 & 6,67 & 3900 \\
\hline 13 & -5 & $m-5 f$ & 4,45 & 2601 & 6,67 & 3900 \\
\hline 14 & -6 & $m-6 f$ & 4,00 & 2342 & 6,67 & 3900 \\
\hline 15 & -7 & $m-7 f$ & 3,56 & 2082 & 6,67 & 3900 \\
\hline $\mathrm{n}=15$ & & & 100,00 & 58500 & 100,05 & 58500 \\
\hline
\end{tabular}

Table 2. Calculation of depreciation by the authors' and the straight-line methods with the planned deceleration step $\mathrm{f}$

\begin{tabular}{|c|c|c|c|c|c|c|}
\hline \multirow[b]{2}{*}{ Period } & \multirow[b]{2}{*}{$\mathrm{K}$} & \multicolumn{3}{|c|}{ Authors' method no. 1 (by an odd number of years) } & \multicolumn{2}{|c|}{ Straight-line method } \\
\hline & & $(\mathrm{m}+\mathrm{K} * \mathrm{f})$ & $* 100 \%$ & $\begin{array}{l}\text { Sum, thousand dollars } \\
C *\left(3^{*} 4\right) / 100\end{array}$ & $m * 100 \%$ & $\begin{array}{l}\text { Sum, thousand dollars } \\
C^{*}(6 / 100)\end{array}$ \\
\hline 1 & -7 & $\mathrm{~m}-7 \mathrm{f}$ & 3,56 & 2082 & 6,67 & 3900 \\
\hline 2 & -6 & $m-6 f$ & 4,00 & 2342 & 6,67 & 3900 \\
\hline 3 & -5 & $m-5 f$ & 4,45 & 2601 & 6,67 & 3900 \\
\hline 4 & -4 & $m-4 f$ & 4,89 & 2861 & 6,67 & 3900 \\
\hline 5 & -3 & $m-3 f$ & 5,33 & 3121 & 6,67 & 3900 \\
\hline 6 & -2 & $m-2 f$ & 5,78 & 3381 & 6,67 & 3900 \\
\hline 7 & -1 & $\mathrm{~m}-\mathrm{f}$ & 6,22 & 3640 & 6,67 & 3900 \\
\hline 8 & 0 & $\mathrm{~m}$ & 6,67 & 3900 & 6,67 & 3900 \\
\hline 9 & +1 & $\mathrm{~m}+\mathrm{f}$ & 7,11 & 4160 & 6,67 & 3900 \\
\hline 10 & +2 & $m+2 f$ & 7,55 & 4419 & 6,67 & 3900 \\
\hline 11 & +3 & $m+3 f$ & 8,00 & 4679 & 6,67 & 3900 \\
\hline 12 & +4 & $\mathrm{~m}+4 \mathrm{f}$ & 8,44 & 4939 & 6,67 & 3900 \\
\hline 13 & +5 & $m+5 f$ & 8,89 & 5199 & 6,67 & 3900 \\
\hline 14 & +6 & $m+6 f$ & 9,33 & 5458 & 6,67 & 3900 \\
\hline 15 & $\begin{array}{l}\text { T0 } \\
+7\end{array}$ & $m+7 f$ & 9,77 & 5718 & 6,67 & 3900 \\
\hline $\mathrm{n}=15$ & & & 100,00 & 58500 & 100,05 & 58500 \\
\hline
\end{tabular}

Table 3. Calculation of depreciation by the authors' and the straight-line methods with the planned acceleration step $2 \mathrm{f}$

\begin{tabular}{|c|c|c|c|c|c|c|}
\hline \multirow[b]{2}{*}{ Period } & \multirow[b]{2}{*}{$\mathrm{K}$} & \multicolumn{3}{|c|}{ Authors' method no. 1 (by an odd number of years) } & \multicolumn{2}{|c|}{ Straight-line method } \\
\hline & & $(\mathrm{m}+\mathrm{K} * \mathrm{f})$ & $* 100 \%$ & $\begin{array}{l}\text { Sum, thousand dollars } \\
C *(3 * 4) / 100\end{array}$ & $\mathrm{~m} * 100 \%$ & $\begin{array}{l}\text { Sum, thousand dollars } \\
C^{*}(6 / 100)\end{array}$ \\
\hline 1 & +14 & $m+14 \mathrm{f}$ & 12,88 & 7536 & 6,67 & 3900 \\
\hline 2 & +12 & $m+12 f$ & 11,99 & 7017 & 6,67 & 3900 \\
\hline 3 & +10 & $m+10 f$ & 11,11 & 6497 & 6,67 & 3900 \\
\hline 4 & +8 & $m+8 f$ & 10,22 & 5978 & 6,67 & 3900 \\
\hline 5 & +6 & $m+6 f$ & 9,33 & 5458 & 6,67 & 3900 \\
\hline 6 & +4 & $m+4 f$ & 8,44 & 4939 & 6,67 & 3900 \\
\hline 7 & +2 & $m+2 f$ & 7,55 & 4419 & 6,67 & 3900 \\
\hline 8 & 0 & $\mathrm{~m}$ & 6,67 & 3900 & 6,67 & 3900 \\
\hline 9 & -2 & $m-2 f$ & 5,78 & 3381 & 6,67 & 3900 \\
\hline 10 & -4 & $m-4 f$ & 4,89 & 2861 & 6,67 & 3900 \\
\hline 11 & -6 & $m-6 f$ & 4,00 & 2342 & 6,67 & 3900 \\
\hline 12 & -8 & $m-8 \mathrm{f}$ & 3,11 & 1822 & 6,67 & 3900 \\
\hline 13 & -10 & $\mathrm{~m}-10 \mathrm{f}$ & 2,23 & 1303 & 6,67 & 3900 \\
\hline 14 & -12 & $\mathrm{~m}-12 \mathrm{f}$ & 1,34 & 783 & 6,67 & 3900 \\
\hline 15 & -14 & $m-14 f$ & 0,45 & 264 & 6,67 & 3900 \\
\hline $\mathrm{n}=15$ & & & 100,00 & 58500 & 100,05 & 58500 \\
\hline
\end{tabular}


Evgeniy Aleksandrovich Filatov et al. / American Journal of Applied Sciences 11 (4): 631-638, 2014

Table 4. Calculation of depreciation by the authors' and the straight-line methods with the planned deceleration step $2 \mathrm{f}$

\begin{tabular}{|c|c|c|c|c|c|c|}
\hline \multirow[b]{2}{*}{ Period } & \multirow[b]{2}{*}{$\mathrm{K}$} & \multicolumn{3}{|c|}{ Authors' method no. 1 (by an odd number of years) } & \multicolumn{2}{|c|}{ Straight-line method } \\
\hline & & $(m+K * f)$ & $* 100 \%$ & $\begin{array}{l}\text { Sum, thousand dollars } \\
\mathrm{C} *\left(3^{*} 4\right) / 100\end{array}$ & $\mathrm{~m} * 100 \%$ & $\begin{array}{l}\text { Sum, thousand dollars } \\
C^{*}(6 / 100)\end{array}$ \\
\hline 1 & -14 & $\mathrm{~m}-14 \mathrm{f}$ & 0,45 & 264 & 6,67 & 3900 \\
\hline 2 & -12 & $m-12 f$ & 1,34 & 783 & 6,67 & 3900 \\
\hline 3 & -10 & $m-10 f$ & 2,23 & 1303 & 6,67 & 3900 \\
\hline 4 & -8 & $\mathrm{~m}-8 \mathrm{f}$ & 3,11 & 1822 & 6,67 & 3900 \\
\hline 5 & -6 & $m-6 f$ & 4,00 & 2342 & 6,67 & 3900 \\
\hline 6 & -4 & $m-4 f$ & 4,89 & 2861 & 6,67 & 3900 \\
\hline 7 & -2 & $m-2 f$ & 5,78 & 3381 & 6,67 & 3900 \\
\hline 8 & 0 & $\mathrm{~m}$ & 6,67 & 3900 & 6,67 & 3900 \\
\hline 9 & +2 & $m+2 f$ & 7,55 & 4419 & 6,67 & 3900 \\
\hline 10 & +4 & $\mathrm{~m}+4 \mathrm{f}$ & 8,44 & 4939 & 6,67 & 3900 \\
\hline 11 & +6 & $m+6 f$ & 9,33 & 5458 & 6,67 & 3900 \\
\hline 12 & +8 & $m+8 f$ & 10,22 & 5978 & 6,67 & 3900 \\
\hline 13 & +10 & $m+10 f$ & 11,11 & 6497 & 6,67 & 3900 \\
\hline 14 & +12 & $m+12 f$ & 11,99 & 7017 & 6,67 & 3900 \\
\hline 15 & +14 & $m+14 f$ & 12,88 & 7536 & 6,67 & 3900 \\
\hline $\mathrm{n}=15$ & & & 100,00 & 58500 & 100,05 & 58500 \\
\hline
\end{tabular}

Table 5. Calculation of depreciation by the authors' and the straight-line methods with the planned acceleration step $\mathrm{f}$

\begin{tabular}{|c|c|c|c|c|c|c|}
\hline \multirow[b]{2}{*}{ Period } & \multirow[b]{2}{*}{$\mathrm{K}$} & \multicolumn{3}{|c|}{ Authors' method no. 2 (by an odd number of years) } & \multicolumn{2}{|c|}{ Straight-line method } \\
\hline & & $(\mathrm{m}+\mathrm{K} * \mathrm{f})$ & $* 100 \%$ & $\begin{array}{l}\text { Sum, thousand dollars } \\
C *\left(3^{*} 4\right) / 100\end{array}$ & $\mathrm{~m} * 100 \%$ & $\begin{array}{l}\text { Sum, thousand dollars } \\
C^{*}(6 / 100)\end{array}$ \\
\hline 1 & +7 & $\mathrm{~m}+7 \mathrm{f}$ & 10,71 & 6268 & 7,15 & 4183 \\
\hline 2 & +6 & $m+6 f$ & 10,20 & 5969 & 7,15 & 4183 \\
\hline 3 & +5 & $m+5 \mathrm{f}$ & 9,69 & 5671 & 7,15 & 4183 \\
\hline 4 & +4 & $m+4 f$ & 9,18 & 5372 & 7,15 & 4183 \\
\hline 5 & +3 & $m+3 f$ & 8,67 & 5074 & 7,15 & 4183 \\
\hline 6 & +2 & $m+2 f$ & 8,16 & 4776 & 7,15 & 4183 \\
\hline 7 & +1 & $\mathrm{~m}+\mathrm{f}$ & 7,65 & 4477 & 7,15 & 4183 \\
\hline 8 & -1 & $m-f$ & 6,63 & 3880 & 7,15 & 4183 \\
\hline 9 & -2 & $m-2 f$ & 6,12 & 3582 & 7,15 & 4183 \\
\hline 10 & -3 & $m-3 f$ & 5,61 & 3283 & 7,15 & 4183 \\
\hline 11 & -4 & $m-4 f$ & 5,10 & 2985 & 7,15 & 4183 \\
\hline 12 & -5 & $m-5 f$ & 4,59 & 2686 & 7,15 & 4183 \\
\hline 13 & -6 & $m-6 f$ & 4,08 & 2388 & 7,15 & 4183 \\
\hline 14 & -7 & $m-7 f$ & 3,57 & 2089 & 7,15 & 4183 \\
\hline $\mathrm{n}=14$ & & & 100,00 & 58500 & 100,10 & 58562 \\
\hline
\end{tabular}

Table 6. Calculation of depreciation by the authors' and the straight-line methods with the planned deceleration step $\mathrm{f}$

\begin{tabular}{|c|c|c|c|c|c|c|}
\hline \multirow[b]{2}{*}{ Period } & \multirow[b]{2}{*}{$\mathrm{K}$} & \multicolumn{3}{|c|}{ Authors' method no. 2 (on an even number of years) } & \multicolumn{2}{|c|}{ Straight-line method } \\
\hline & & $(m+K * f)$ & $* 100 \%$ & $\begin{array}{l}\text { Sum, thousand dollars } \\
\mathrm{C} *\left(3^{*} 4\right) / 100\end{array}$ & $\mathrm{~m} * 100 \%$ & $\begin{array}{l}\text { Sum, thousand dollars } \\
C^{*}(6 / 100)\end{array}$ \\
\hline 1 & -7 & $m-7 f$ & 3,57 & 2089 & 7,15 & 4183 \\
\hline 2 & -6 & $m-6 f$ & 4,08 & 2388 & 7,15 & 4183 \\
\hline 3 & -5 & $m-5 f$ & 4,59 & 2686 & 7,15 & 4183 \\
\hline 4 & -4 & $m-4 f$ & 5,10 & 2985 & 7,15 & 4183 \\
\hline 5 & -3 & $m-3 f$ & 5,61 & 3283 & 7,15 & 4183 \\
\hline 6 & -2 & $m-2 f$ & 6,12 & 3582 & 7,15 & 4183 \\
\hline 7 & -1 & $m-f$ & 6,63 & 3880 & 7,15 & 4183 \\
\hline 8 & +1 & $m+f$ & 7,65 & 4477 & 7,15 & 4183 \\
\hline 9 & +2 & $m+2 f$ & 8,16 & 4776 & 7,15 & 4183 \\
\hline 10 & +3 & $m+3 f$ & 8,67 & 5074 & 7,15 & 4183 \\
\hline 11 & +4 & $m+4 f$ & 9,18 & 5372 & 7,15 & 4183 \\
\hline 12 & +5 & $m+5 f$ & 9,69 & 5671 & 7,15 & 4183 \\
\hline 13 & +6 & $m+6 f$ & 10,20 & 5969 & 7,15 & 4183 \\
\hline 14 & +7 & $m+7 f$ & 10,71 & 6268 & 7,15 & 4183 \\
\hline $\mathrm{n}=14$ & & & 100,00 & 58500 & 100,10 & 58562 \\
\hline
\end{tabular}


Evgeniy Aleksandrovich Filatov et al. / American Journal of Applied Sciences 11 (4): 631-638, 2014

Table 7. Calculation of depreciation by the authors' and the straight-line methods with the planned acceleration step $2 \mathrm{f}$

\begin{tabular}{|c|c|c|c|c|c|c|}
\hline \multirow[b]{2}{*}{ Period } & \multirow[b]{2}{*}{$\mathrm{K}$} & \multicolumn{3}{|c|}{ Authors' method no. 2 (on an even number of years) } & \multicolumn{2}{|c|}{ Straight-line method } \\
\hline & & $(m+K * f)$ & $* 100 \%$ & $\begin{array}{l}\text { Sum, thousand dollars } \\
\mathrm{C} *(3 * 4) / 100\end{array}$ & $\mathrm{~m} * 100 \%$ & $\begin{array}{l}\text { Sum, thousand dollars } \\
C^{*}(6 / 100)\end{array}$ \\
\hline 1 & +13 & $\mathrm{~m}+13 \mathrm{f}$ & 13,78 & 8059 & 7,15 & 4183 \\
\hline 2 & +11 & $m+11 f$ & 12,76 & 7462 & 7,15 & 4183 \\
\hline 3 & +9 & $m+9 f$ & 11,73 & 6865 & 7,15 & 4183 \\
\hline 4 & +7 & $m+7 f$ & 10,71 & 6268 & 7,15 & 4183 \\
\hline 5 & +5 & $m+5 f$ & 9,69 & 5671 & 7,15 & 4183 \\
\hline 6 & +3 & $m+3 f$ & 8,67 & 5074 & 7,15 & 4183 \\
\hline 7 & +1 & $\mathrm{~m}+\mathrm{f}$ & 7,65 & 4477 & 7,15 & 4183 \\
\hline 8 & -1 & $m-f$ & 6,63 & 3880 & 7,15 & 4183 \\
\hline 9 & -3 & $m-3 f$ & 5,61 & 3283 & 7,15 & 4183 \\
\hline 10 & -5 & $m-5 f$ & 4,59 & 2686 & 7,15 & 4183 \\
\hline 11 & -7 & $m-7 f$ & 3,57 & 2089 & 7,15 & 4183 \\
\hline 12 & -9 & $m-9 f$ & 2,55 & 1492 & 7,15 & 4183 \\
\hline 13 & -11 & $\mathrm{~m}-11 \mathrm{f}$ & 1,53 & 895 & 7,15 & 4183 \\
\hline 14 & -13 & $\mathrm{~m}-13 \mathrm{f}$ & 0,51 & 298 & 7,15 & 4183 \\
\hline $\mathrm{n}=14$ & & & 100,00 & 58500 & 100,10 & 58562 \\
\hline
\end{tabular}

Table 8. Calculation of depreciation by the authors' and the straight-line methods with the planned deceleration step $2 \mathrm{f}$

\begin{tabular}{|c|c|c|c|c|c|c|}
\hline \multirow[b]{2}{*}{ Period } & \multirow[b]{2}{*}{$\mathrm{K}$} & \multicolumn{3}{|c|}{ Author’s method № 2 (on an even number of years) } & \multicolumn{2}{|c|}{ Straight-line method } \\
\hline & & $(\mathrm{m}+\mathrm{K} * \mathrm{f})$ & $* 100 \%$ & $\begin{array}{l}\text { Sum, thousand dollars } \\
\mathrm{C} *(3 * 4) / 100\end{array}$ & $\mathrm{~m} * 100 \%$ & $\begin{array}{l}\text { Sum, thousand dollars } \\
C^{*}(6 / 100)\end{array}$ \\
\hline 1 & -13 & $m-13 f$ & 0,51 & 298 & 7,15 & 4183 \\
\hline 2 & -11 & $\mathrm{~m}-11 \mathrm{f}$ & 1,53 & 895 & 7,15 & 4183 \\
\hline 3 & -9 & $m-9 f$ & 2,55 & 1492 & 7,15 & 4183 \\
\hline 4 & -7 & $m-7 f$ & 3,57 & 2089 & 7,15 & 4183 \\
\hline 5 & -5 & $m-5 f$ & 4,59 & 2686 & 7,15 & 4183 \\
\hline 6 & -3 & $m-3 f$ & 5,61 & 3283 & 7,15 & 4183 \\
\hline 7 & -1 & $m-f$ & 6,63 & 3880 & 7,15 & 4183 \\
\hline 8 & +1 & $\mathrm{~m}+\mathrm{f}$ & 7,65 & 4477 & 7,15 & 4183 \\
\hline 9 & +3 & $m+3 f$ & 8,67 & 5074 & 7,15 & 4183 \\
\hline 10 & +5 & $m+5 f$ & 9,69 & 5671 & 7,15 & 4183 \\
\hline 11 & +7 & $m+7 f$ & 10,71 & 6268 & 7,15 & 4183 \\
\hline 12 & +9 & $m+9 f$ & 11,73 & 6865 & 7,15 & 4183 \\
\hline 13 & +11 & $m+11 f$ & 12,76 & 7462 & 7,15 & 4183 \\
\hline 14 & +13 & $m+13 f$ & 13,78 & 8059 & 7,15 & 4183 \\
\hline $\mathrm{n}=14$ & & & 100,00 & 58500 & 100,10 & 58562 \\
\hline
\end{tabular}

\section{ANALYSIS AND RESULTS}

Figure 1 pictorially shows that depreciation rate under in-line method as an example 1 , where $n$ was equal to 15 years made $6,67 \%$ or 3900 thousand dollars. In author's method during this period of time depreciation rate ranged from 0,45 to $12,88 \%$ or from 264 thousand dollars to 7536 thousand dollars. Total amount of amortization expenses by the example 1 under in-line method came to 100,05 and generated variance for 0,05 amounting to 500 thousand dollars. While author's methods by the example 1 elicit not any common variances.
Figure 2 pictorially shows that depreciation rate under in-line method as an example 2, where $\mathrm{n}$ was equal to 14 years made $7,15 \%$ or 4183 thousand dollars. In author's method during this period of time depreciation rate ranged from $0,51 \%$ to 13,78 or from 298 thousand dollars to 8059 thousand dollars. Total amount of amortization expenses by the example 2 under in-line method came to $100,10 \%$ and generated variance for $0,10 \%$ amounting to 562 thousand dollars. While author's methods by the example 2 elicit not any common variances. 

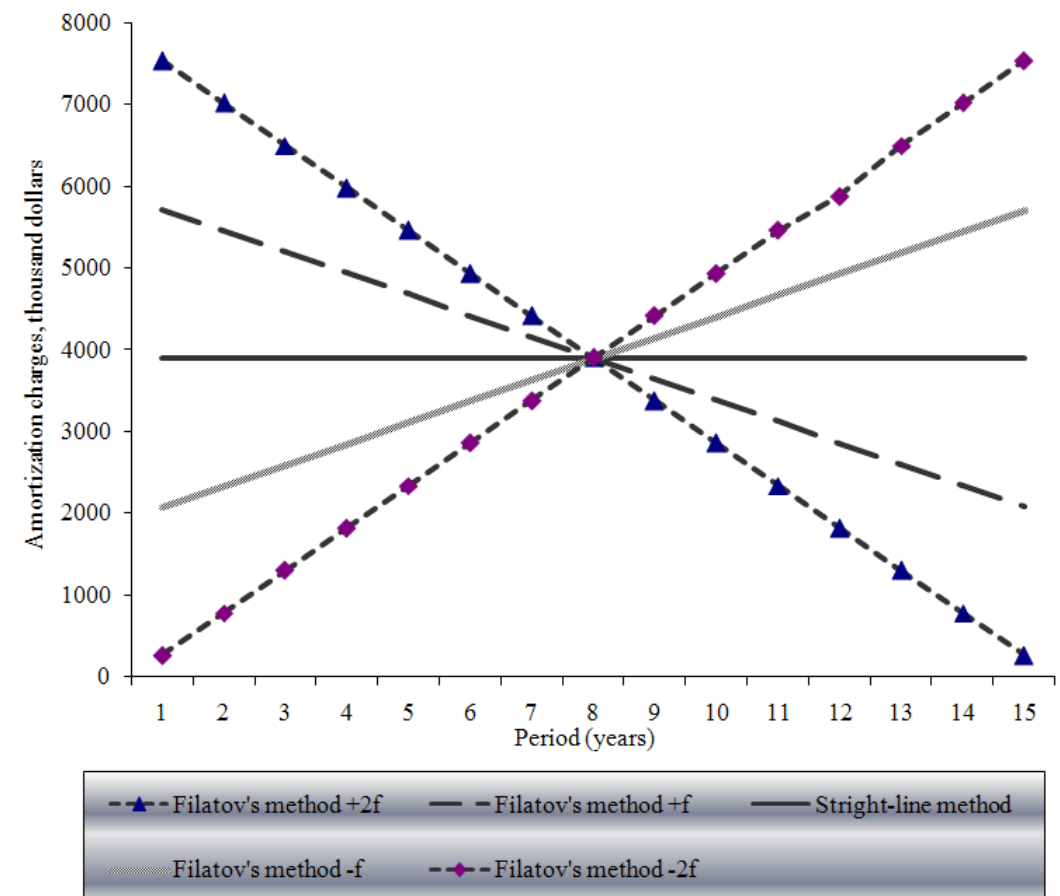

Fig. 1. Size comparison of depreciation calculated by the authors' method no. 1 (odd number of years) and the straight-line method with the planned step of acceleration $(+\mathrm{f}$ and $+2 \mathrm{f}$ ) and deceleration ( $-\mathrm{f}$ and $-2 \mathrm{f})$

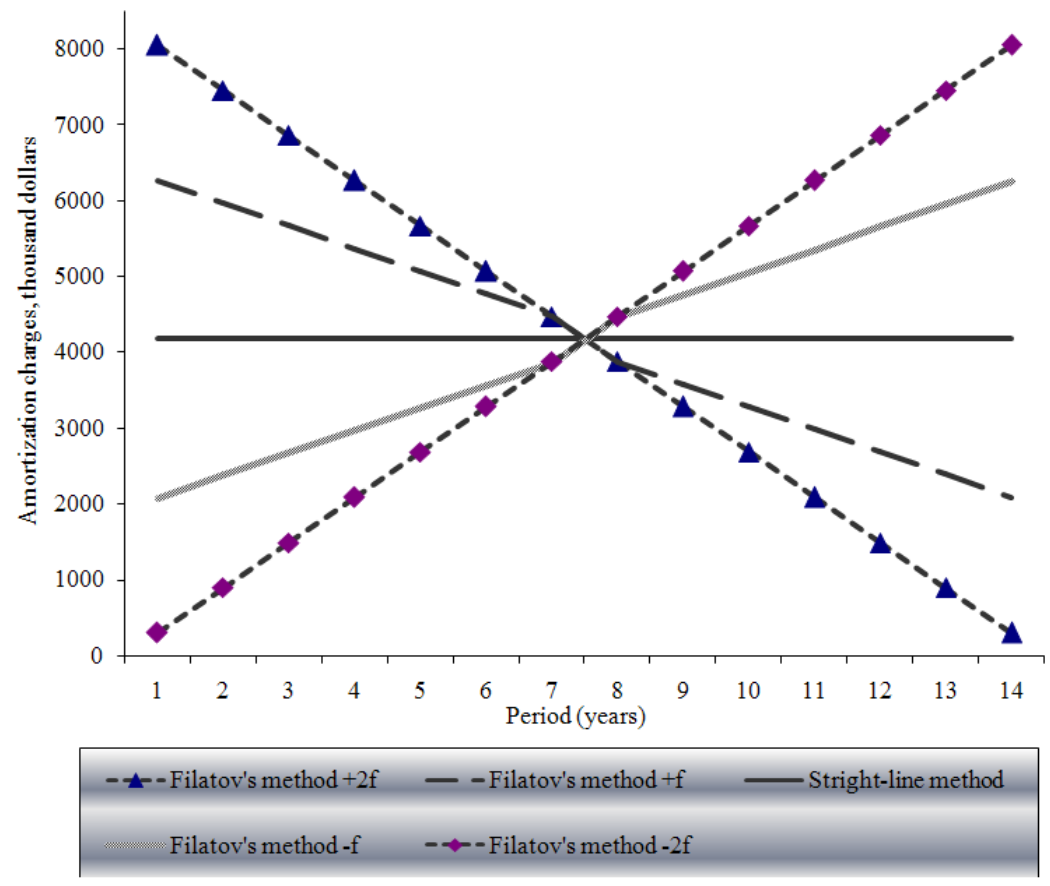

Fig. 2. Size comparison of depreciation calculated by the authors' method no. 2 (even number of years) and the straight-line method with the planned step of acceleration $(+\mathrm{f}$ and $+2 \mathrm{f}$ ) and deceleration (- $\mathrm{f}$ and $-2 \mathrm{f})$ 
Consequently, it may be concluded that author's methods of variational calculations of depreciation policy formation allow economic entity to form and allocate amortization funds more rationally.

\section{DISCUSSION}

It is known that capital assets are taken up to get revenue during several years. The period of using capital assets the part of their cost is written to expenses by means amortization (Hoffman, 2013).

Depreciation takes special place under forecast of financial flows. It is disclosed in financial statements of an organization as well calculation such capital financial ratios (Pratt and William, 2013).

Depreciation policy plays important role in strategic and current management of organization, for instance, in pricing, tax revenue, expenses and returns regulation, property and collaterial assessment, rent payment determination. Development of effective depreciation policy will help in making decisions on business management.

Development of effective depreciation policy is quite difficult and multi aspect problem and to find the most acceptable and appropriate solution it is necessary to pay into account each stage of economic development.

Initial cost of capital funds item will benever written off under declining balance method. Declining balance method and sum-of-years' depreciation method are based on the principle of cumulative assessment costs of amortization expenses. These methods allow to write off maximum amortization cost at the beginning of assets' work. Besides under sum-of-years' depreciation method converse cumulative digit can be used and it slows amortization cost at the beginning of assets work, but in contrast with author's method this method make more acute fluctuations of amortization rate years out. In accordance with the line method it is possible to write off only equal sum of amortization expenses.

Author's method presented above resolve all problems integral to traditional methods of depreciation charging.

\section{SUMMARY}

The reasons to use the methods of accelerated (decelerated) depreciation are the following:

- The highest intensity of the use of fixed assets is accounted for the first years of their operation when they are still physically and mentally new

- The funds for the replacement of an depreciable asset are accumulated in case of its rapid obsolescence and inflation
- It is possible to increase the cost of reparation of depreciable assets which is due during the last years of the use of the assets without the corresponding increase in production costs (because of the fact that the amount of depreciation calculated in these years is reduced)

When using a retarded (progressive) depreciation the management of companies increases profits and reduces net costs in the first years of operation of the assets thereby increasing the investment attractiveness of the company, its financial results and financial position.

In many countries, for quite long periods of time, the methods of self-financing of the investment process and the expanded reproduction of the fixed capital have been achieved through depreciation. In the countries with stable economies and well-balanced tax systems along with the linear methods nonlinear methods of calculation with acceleration and deceleration of the returned funds are widely used. Therefore, the depreciation policy methods developed by the authors are better as compared to the known ones and they contribute to the quality of management, strengthen its control and analytic functions for the strategic regulation of the investment process.

\section{CONCLUSION}

Currently, due to the international financial and economic crisis the industries and businesses instead of straight-line methods use complex methods, the former being popular in the past and still in wide use in developing countries.

The authors' methods offer a new and effective mechanism, which is devoted to organization of an effective management of the capital using a new approach in depreciation calculation for time periods. This new mechanism is useful for different industrial companies and management's levels as an innovative theoretical strategy.

More over on grounds of author's methods presented above it is possible to make secondary methods where adjustment factor $\mathrm{K}$ will be with not clear sequence, for example $+1,+5,+8,-1,-5,-8$ and other all kinds of variations.

\section{REFERENCES}

Altahat, E., A. AL-Sharafat and M. Altarawneh, 2012. Factors affecting profitability of layer hens enterprises. Am. J. Agric. Biol. Sci., 7: 106-113. DOI: 10.3844/ajabssp.2012.106.113 
Auerbach, A.J., 1983. Taxation, corporate financial policy and the cost of capital. J. Econ. Literature, 21: 905-940.

Cohen, R., 1975. Investment behavior, the measurement of depreciation and tax policy. Am. Econ. Rev., 65: 59-74.

Cohen, R., 1980. Depreciation, Profits and Rates of Return in Manufacturing Industries. In: The Measurement of Capital, Studies in Income and Wealth, National Bureau of Economic Research, Usher, D. (Ed.), The University of Chicago Press, Chicago.

Doms, M.E., 1996. Estimating capital efficiency schedules within production functions. Econ. Inquiry, 34: 78-92. DOI: 10.1111/j.14657295.1996.tb01365.x

Feldstein, M.A., 1982. Inflation, tax rules and investment: some econometric evidence. Econometrica, 50: 825-862. DOI: 10.2307/1912766
Filatov, E.A., 2013. Depreciation Policy for the Purposes of Investment Development of Commercial Organizations: Monograph/Irkutsk: EPD BSUEL, pp: 92.

Fullerton, D. and R.H. Gordon, 1983. A Reexamination of Tax Distortions in General Equilibrium Models. In: Behavioral Simulation Methods in Tax Policy Analysis, Feldstein, M. (Ed.), The University of Chicago Press, Chicago.

Hall, R.E. and D.W. Jorgenson, 1967. Tax policy and investment behavior. Am. Econ. Rev., 57: 391-414.

Hoffman, W.H., 2013. South-Western Federal Taxation.

Hulten, C.R. and F.C. Wykoff, 1996. Issues in the measurement of economic depreciation introductory remarks. Econ. Inquiry, 34: 10-23. DOI: 10.1111/j.1465-7295.1996.tb01361.x

Pratt, J.W. and K.N. William, 2013. Federal Taxation. 